\title{
Interactive comment on "Singular spectrum and principal component analysis of soil radon (Rn-222) emanation for better detection and correlation of seismic induced anomalies" by Timangshu Chetia et al.
}

Timangshu Chetia et al.

timangshuchetia99@gmail.com

Received and published: 27 August 2019

We are very grateful and convey our sincere thank you to your generous comments and significant suggestion for the manuscript. We have revised the manuscript to best of our knowledge as per your comments and suggestions. We have submitted our response in the "npg-2019-37-supplement.zip" folder as a supplement which contains pdf documents of the following: 1. Reply to Anonymous Referee \#1 2. REVISED MANUSCRIPT WITH TRACK CHANGE 3. REVISED MANUSCRIPT (Without track change)

Printer-friendly version

Discussion paper 
Please also note the supplement to this comment:

NPGD

https://www.nonlin-processes-geophys-discuss.net/npg-2019-37/npg-2019-37-AC1supplement.zip

Interactive comment on Nonlin. Processes Geophys. Discuss., https://doi.org/10.5194/npg-

Interactive

comment 2019-37, 2019. 